\title{
The Correlation between the Environmental Risk Factors and Typhoid Disease Among Children and their Care Givers, Alqalioubiya Governorate
}

\author{
RANDA H. ABDELFATTAH, M.Sc.; ENASS H. ELSHAIR, D.N.Sc. and EBTESAM M. ELSAYED, D.N.Sc.
} The Department of Community Health Nursing, Faculty of Nursing, Cairo University

\begin{abstract}
Background: Typhoid disease remains an important preventable public health problem. Typhoid is found all over the world, but the areas of risk include East and Southeast Asia and Africa particularly Egypt, most of typhoid deaths occur in children of school age or younger.
\end{abstract}

Aim of Study: To assess the correlation between the environmental risk factors and typhoid disease among children and their care givers, Alqalioubiya governorate.

Material and Methods: A descriptive correlative research design was utilized. Setting; study was conducted in 4 villages at Alqalioubiya governorate. A simple random sample of 313 participants was selected. Two tools were used; 1 st tool a structured interviewing questionnaire includes 3 parts demographic data, Knowledge and practices of the caregivers toward typhoid. ${ }^{\text {nd }}$ tool an observational checklist for the home environment.

Results: Reveals that $47.9 \%$ of participants were aged 20 to less than 30 years old with mean $\pm \mathrm{SD}=29.76 \pm 7.36$. All participants had governmental water while $46 \%$ found it unsafe for drinking and food preparation. One fifth kept water tanks in bathrooms, moreover; $32 \%$ kept it unclean and $9.4 \%$ stored it till water turned off. All participants had trenches sewage disposal system. There were a highly statistically significant negative correlation found between the total knowledge and the family history toward typhoid $(p=0.000)$. There were a highly statistically significant positive correlation found between the total knowledge and Total practice scores $(p=0.000)$.

Conclusion: That risk of typhoid transmission not only affected by sanitation of the environment but also the practices within this environment.

Recommendations: Health education program to increase public awareness for typhoid prevention and regular examination of food handlers. Safe water supply program and continuous monitoring to detect any leakage or fecal contamination.

Correspondence to: Dr. Randa H. Abdelfattah, The Department of Community Health Nursing, Faculty of Nursing, Cairo University
Key Words: Environmental risk factors - Typhoid disease and care givers.

\section{Introduction}

EGYPT is one of the developing countries where there is an increasing trend to typhoid disease. Factors that contribute to the spread of these diseases in Egypt include unsanitary environmental risk factors, unhealthy lifestyle, human biology, close contact with infectious vectors and lack of access to health care services [1].

Typhoid disease remains an important preventable public health problem in developing countries including Egypt. Typhoid is found all over the world, but the areas of risk include East and Southeast Asia and Africa particularly Egypt, most of typhoid deaths occur in children of school age or younger [2] . Children are at the greatest risk of getting the disease, although they generally have milder symptoms than adults because they are closely contact to the home environment [3] .

The environmental risk factors either indoor or outdoor factors are the major contributing factor that increase the sustainability of the spread of the typhoid disease. The indoor and outdoor environmental risk factors for typhoid include unhealthy sources and poor quality of potable water supply, sanitation and improper sewage disposal methods. Furthermore, inadequate housing conditions, unsafe food storage methods and lack of hygiene especially among food handlers [4]. He low percentage of the gross national product spent on health together with high poverty rate also exert immense pressure on both the environment and health manifested in lack of basic human needs, such as adequate and nutritious food, clothing, housing, clean water, and health services [5]. 
The indoor environmental risk factors that increase the sustainability for typhoid include the close contact with infected or recently infected individuals, poor hygiene practices especially before handling food, after using the bathroom, touching feces and changing diapers, eating raw fruits and vegetables that cannot be peeled, eating of food handled by an infected person or carrier and poor water and sewage treatment facilities at the home environment [6]

Typhoid is treated by antibiotics successfully but even after treatment a small number of people who recover from typhoid continue to harbor the bacteria in their intestinal tracts or gallbladders and become chronic carriers who shed the bacteria in their feces and are capable of infecting others, although they no longer have signs or symptoms of the disease them As many as 1 in 6 people have the capacity to be a silent carrier. These individuals are particularly dangerous within high-risk populations [3].

The community health nurses plays crucial role in prevention and control of typhoid diseases through responding to public health problems; ensuring the utilization of available health services, providing health education and care management to vulnerable groups (individuals and families), elevating the public awareness toward personal hygiene; provision of a safe water supply and proper sanitation systems [7].

\section{Significance of the study:}

Typhoid is a serious food borne disease. Some people who get typhoid become "chronic carriers," who can spread the disease to others. According to Centers for Disease Control and Prevention (CDC), an estimated 22 million cases of typhoid disease and 200,000 related deaths occur worldwide each year [8]. In endemic areas, children aged 15 years are at the highest risk of infection [9] Mogasale, et al., estimated that 11.9 million typhoid fever illnesses and 129000 deaths occurred in lowincome and middle-income countries [10]. The incidence of typhoid in Egypt is about 10-100/100 000 cases/year [11]

Hundreds of people have contracted typhoid disease. Alqalioubiya, with 276 cases, was the worst hit governorate. While government officials blamed the cases that appeared in Alqalioubiya on groundwater pumps widely used in rural areas where treated drinking water is not available. Residents of Al-Baradaa village where the highest number of cases were confirmed believe the con- tamination occurred in the potable water network [12].

Despite typhoid infection is a frequent public health problem in developing countries, few reports aimed to study the relationship of family human habits and behavior to the environmental sanitation and prevalence of infectious diseases. The diseases transmitted through the fecal-oral cycle, such as typhoid, are an index of the environment's microbial contamination. This situation increases the risk of contagion if people do not have good hygienic habits. This health problem increases the burden on the community health and the cost on the ministry of health [11].

The population-based incidence of typhoid fever at Fayoum Governorate, it was estimated that the incidence of typhoid was 59/100,000 persons/year. Few articles studied the influence of unhealthy environmental and hygienic habits on transmission of fecal-oral diseases among Egyptians in rural area [13]. So the aim of the study was to assess the correlation between the environmental risk factors and typhoid disease among children and their care givers, Alqalioubiya governorate.

\section{Patients and Methods}

The study was carried out on four villages at Alqalioubiya governorate as followed Tahanoob, Kafr Taha, Elzahweieen and Elzawia from 3/2015 to $9 / 2015$

\section{Setting of the study:}

The study was conducted in 4 villages at Alqalioubiya governorate. The geographical map of Alqalioubiya governorate consists of four sectors (north, south, east and west). The east sector of Alqalioubiya governorate was selected. This sector consist 9 centers. Shibin El qanater center was selected. This center consists of 36 villages. Four villages were selected as $10 \%$ of the total villages' number.

The 4 villages have family health centers that rendered to provide primary health care activities and family medicine to serve the people at this area. These villages are famous for poverty, low education level; spread of unhealthy habits, absence of safe water supply and refuse sewage disposal system. The family health centers of these villages have family filling system that helped the research investigator to select the study sample and their addresses for the home visits to fill-in the study tools. 


\section{Sample of the study:}

A simple random sample of 313 caregivers having children aged from one to five years attending to one of the selected family health centers with the following inclusion criteria: Agree to participate in the study, have one or more child aged from1-5 years, Caregiver for children of both gender. According to the health records of the selected family health centers, the average number of children aged from 1-5 years and their caregivers attending to the selected family health centers in one year (2013) was 3125 child. $10 \%$ of that number of children and their caregivers were included as a study subjects which equals 313 participants. Participants and their children were visited at their homes after randomly selected from the family centers files with their home addresses. Thus, the aim of the study was explained and fills in the study tools.

\section{Tools of the study:}

Two tools were developed and tested for validity by 7 panels of experts in community health specialty.

The First tool is a structured interviewing questionnaire to collect data about risk factors and typhoid disease. The questionnaire consists of 39 questions and grouped in 3 parts as follows:

1 st Part:Demographic data include ten questions for demographic characteristics either for the participant and the child such as gender, age, educational level, occupation, the marital status and the family member number.

2nd Part: General knowledge about typhoid disease include nine questions for both the family history and general knowledge of the caregivers about typhoid disease include typhoid infectivity, the nature of the disease, is it curative, its mode of transmission, the common affected age group and it's the risk factors

$3 r d$ Part: The health practices of the participants toward typhoid risk factors include 4 parameters as follows food habits, food hygiene, personal hygiene and self reported home environment risk factors. The food habits such as what are the regular meals eaten by the child, all meals prepared at home and is the out door meals cooked or raw meals. The food hygiene such as how to clean fruits and vegetables, who is the best to wash food contents, cleans the kitchen equipment between different types of food and is the foods stored at refrigerator washed and clean. The personal hygiene such as hand washing after retune back to home, hand washing regularly after toileting, food preparation and before eating. The home environment risk factors such as the source of water at home, is it safe for drinking and food preparation, how to clean the water to make it safe for usage, are there water store tanks, where is it at the home environment, for how long do you store the water, is there sewage disposal system for the home, what is the type of the sewage disposal system for the home and how to discard the food wastes.

The second tool: An observational checklist for the home environment to collect data about the indoor and the outdoor environment. It include 26 questions about cleanness level, presence of insects in and out the home, home location and garbage, source of water, food handling and waste disposal in and out the home.

\section{Scoring system:}

Scoring system of the study tools were calculated by giving a 2 score for the correct answers and 1 for the wrong answers then a total score is calculated. The total score of knowledge and practice was converted to $100 \%$ and then categorized as follows: From $75 \%$ or more of the total sum of the correct answer equal adequate knowledge or practice, from 60 - and less than $75 \%$ equal fair knowledge or practice and less than $60 \%$ equal inadequate knowledge or practice.

Ethical consideration: An approval of the ethical research committee of the faculty of nursing, Cairo University obtained to carry out the current study; primary approval obtained at 23/3/2014 and the final approval obtained in 5/2016. An official permission obtained from the centers administrators' and a formal written consent was obtained from the caregivers after being informed about the purpose and nature of the study. The research investigator emphasized that participation in the study is completely voluntary, anonymity and confidentiality was assured.

Procedure: An official written permission was obtained from the Faculty of Nursing, Cairo University and the directors of the family health centers to select the sample and their addresses from the family health center records. Participants were visited at their homes and so the aim and the nature of the study were explained. Participant rights such as accepting or refusing participation in the study and confidentiality of their data were clarified and so a written informed consent was obtained from every participant who accepted to participate in the study. The first tool was filled in by the research investigator from each participant and the second 
tool was filled in after observing the home environment. Time spent to fill in the study tools ranged between 20 to 30 minutes. Data were collected for 6 months, two days every week.

Statistical Analysis: Data were scored, tabulated and analyzed by personal computer using Statistical Package for the Social Sciences (SPSS) program version 20. As descriptive as well as inferential statistics was utilized to analyze data pertinent to the study. Level of significant was set at $p<0.05$; $p$-value is the degree of significance.

\section{Results}

Regarding participants' age, results revealed that $48 \%$ of them aged between 20 to less than 30 years old while, $40.9 \%$ aged between 30 to less than 40 years moreover, $4.5 \%$ were less than 20 years. Moreover those who were 50 years and more constitute $3.2 \%$ with mean $\pm \mathrm{SD}=29.76 \pm 7.36$. Concerning gender of participants', $93 \%$ of them were females while only $7 \%$ were males.

Regarding educational level, $41.2 \%$ of participants' had moderate education (diploma or institute), followed by $29.1 \%$ who had basic education (primary -preparatory) and $23.3 \%$ who had university education while $3.8 \%$ who can't read or write and those who can read and write constitute $2.6 \%$. Results also illustrate that more than $76.4 \%$ of participant were house wives, $16.9 \%$ of participants' were employee and $6.1 \%$ of them were handicrafts. Regarding knowledge of participants' about typhoid, $57.8 \%$ of participant had adequate level of knowledge while $42.2 \%$ of them had fair level of knowledge.

Regarding participants' indoor and outdoor practices within the home environment toward food habits, $32.6 \%$ of participants' mentioned that they Sale/bring out door meals while $67.4 \%$ mentioned they don't sale/bring out door meals. Respectively $92.2 \%$ of them sale out door meals from shop or restaurant while $7.8 \%$ sale from Peddlers sold at streets. Moreover $91.2 \%$ of the out door meals were cooked meals while $8.8 \%$ were raw food. All participants' mentioned that they sale out door drinks such as Sugarcane juice and licorice juice.

Regarding participants' practices toward food hygiene within the home environment, $92.7 \%$ reported that they ate fruits and vegetables washed while $7.3 \%$ ate it without washing. As regards cleaning fruits and vegetables $66.8 \%$ of the participants' clean it in running water, $24.9 \%$ clean it by soaking in a pot of water and vinegar while $8.3 \%$ soak it in a vase of water. Moreover $98.1 \%$ of participants' mentioned that they clean the kitchen equipment between different types of food while $1.9 \%$ of them don't. Concerning keep food washed and cleaned in the refrigerator only $9.9 \%$ of participants' mentioned that they keep food washed and cleaned in the refrigerator while $90.1 \%$ keep it not washed.

Regarding participants' practices toward personal hygiene at the home environment, $58.1 \%$ of Participants mentioned that they wash hands after retune to home while $41.9 \%$ don't. As regards wash hands after toilet $33.5 \%$ of participants' mentioned that they regularly wash hands after toilet while $66.5 \%$ don't regularly wash hands after toilet. Moreover $97.1 \%$ of participants' mentioned that they wash their hands before food preparation while $2.9 \%$ doesn't do this. Concerning wash hands before eating only $7.3 \%$ of participants' mentioned that they regularly wash their hands before eating while $90.7 \%$ of them don't do.

As regards participants' self reported home environment, all Participants had governmental source of water while only $54 \%$ of participants' found the available source of water adequate for drinking and food. Regarding water storage, $98.7 \%$ of Participants had water tanks at home. Moreover $80.6 \%$ of participants' kept water tanks in the kitchen and $19.4 \%$ keep it in the bathroom. Concerning period of storing water, $9.4 \%$ stored it till water turned off (it may lasts for months). All participants' have trenches sewage disposal system at home. As regards food wastes, 53\% of Participants collect food wastes in a bag into the basket to discharge it while $47 \%$ put it for the home birds $\&$ animals.

As observed by the research investigator, $80.8 \%$ of participants' home were fare from pollution of and $32.3 \%$ were near the garbage collections. Further more, $57.8 \%$ of participants' home was well ventilated. Regarding insects, $60.4 \%$ 0f Participants had insects inside the home. Respectively $52.1 \%$ of participants' Control insects inside the home while $47.9 \%$ don't control it. All participants' home had special kitchen for their home, 78.9\% of them kept it clean. Almost of participants' (98.4\%) Washed food equipments before usage and also food content before eating Further more, $55.3 \%$ of participants' had all kitchen outlets covered by intact silk. All participants' had garbage container in the kitchen, $68.7 \%$ of them were properly closed. 
Regarding water, all participants' home have governmental source of water. Meanwhile, $56.5 \%$ of the available water source is appropriate for drinking while $43.5 \%$ isn't appropriate for drinking. Concerning water tanks, $32 \%$ of participants' kept Water storage tanks unclean. All Participants homes have a special bathroom, $48.9 \%$ were unclean. The table also shows that $47 \%$ of Participants discharge their food wastes in closed bags. Furthermore $72.5 \%$ of participants' collect garbage outside the home and $63.9 \%$ don't keep it covered.

There was a highly statistically significant correlation between the study subject's job and the previous family history of typhoid $(p=0.004)$.

Table (1): Correlation between demographic data of participants' and the family previous history of typhoid $(n=313)$.

\begin{tabular}{|c|c|c|c|c|}
\hline \multirow{2}{*}{$\begin{array}{l}\text { Demographic } \\
\text { data }\end{array}$} & \multicolumn{2}{|c|}{$\begin{array}{l}\text { The previous } \\
\text { family history }\end{array}$} & \multicolumn{2}{|c|}{$\begin{array}{l}\text { The infected } \\
\text { person }\end{array}$} \\
\hline & $r$ & $p$-value & $r$ & $p$-value \\
\hline The job & & $* 0.004$ & & 0.201 \\
\hline Care giver's age & 0.029 & 0.641 & 0.116 & 0.598 \\
\hline $\begin{array}{l}\text { Care giver's } \\
\text { educational level }\end{array}$ & -0.253 & 0.253 & -0.143 & 0.516 \\
\hline Crowding index & 0.031 & 0.587 & 0.135 & 0.538 \\
\hline
\end{tabular}

* Correlation is significant at the 0.01 level.
There was a highly statistically significant negative correlation found between the total knowledge and the family previous history toward typhoid $(p=0.000)$. While there were no statistically significant correlation found between total practice and total environmental risk factors and the family previous history of typhoid.

As regards correlation between the total knowledge, total practice and total environment of the study subjects with each other. There was a highly statistically significant positive correlation found between the total knowledge and Total practice scores $(p=0.000)$. While there was no statistically significant correlation found between total knowledge scores and total environmental scores.

Table (2): Correlation between the total knowledge, total practice and total environmental risk factors and the family previous history of typhoid.

\begin{tabular}{lcc}
\hline \multirow{2}{*}{ Correlation } & \multicolumn{2}{c}{$\begin{array}{c}\text { The previous } \\
\text { family history }\end{array}$} \\
\cline { 2 - 3 } & $r$ & $p$-value \\
\hline Total knowledge scores & -0.251 & $* 0.000$ \\
Total practice scores & 0.320 & 0.320 \\
Total environmental scores & 0.032 & 0.572 \\
\hline
\end{tabular}

* Correlation is significant at the 0.01 level.

Table (3): Correlation between the total knowledge, total practice and total environment of the study subjects with each other.

\begin{tabular}{|c|c|c|c|c|c|c|}
\hline \multirow{2}{*}{ Correlation } & \multicolumn{2}{|c|}{ Total knowledge } & \multicolumn{2}{|c|}{ Total practice } & \multicolumn{2}{|c|}{ Total environmental } \\
\hline & $\begin{array}{l}\text { Correlation } \\
\text { coefficient }\end{array}$ & $p$-value & $\begin{array}{l}\text { Correlation } \\
\text { coefficient }\end{array}$ & $p$-value & $\begin{array}{l}\text { Correlation } \\
\text { coefficient }\end{array}$ & $p$-value \\
\hline Total knowledge & & & 0.374 & $* 0.000$ & 0.109 & 0.053 \\
\hline Total practice & 0.374 & $* 0.000$ & & & 0.102 & 0.071 \\
\hline Total environment & 0.109 & 0.053 & 0.102 & 0.071 & & \\
\hline
\end{tabular}

* Correlation is significant at the 0.01 level.

\section{Discussion}

Total knowledge level

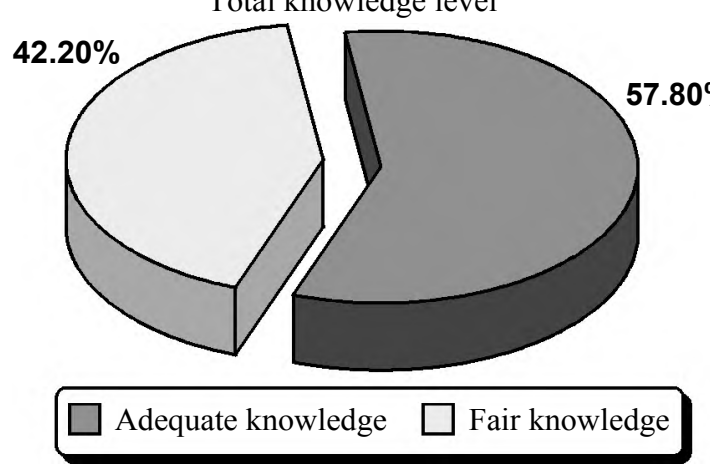

Fig. (1): Illustrate the total knowledge level of the participants.
Results of the current study revealed that majority of Participants were females. This finding is not congruent with the study done by Malisa and Nyaki [14] on 120 participants in Tanzania to study Prevalence and constraints of typhoid fever and its control in an endemic area of Singida region in Tanzania: Lessons for effective control of the disease that found around two third were females and forty percent were males.

The age of the Participants has direct effect on the level of care provided. The result of the current 
study revealed that about half of study subjects their age were between 20 and less than 30 years with mean age $29.76 \pm 7.36$. Such result was in agreement with the result of a study done by Naqqash, Saeed, Saeed, Jaleel, Zaka, Faheem, Bakhtawar and Rehman [15] on five hundred people of Southern Punjab, Pakistan that found half of the participants aged between 19 and 30 years.

The result of the current study revealed that more than one third of Participants had secondary education or diploma. Followed by, more than one quarter had primary education (primary or preparatory). This result was supported by a study done by Nguri [16] on 350 participants in Kenya that found one third of the participants had secondary education. In my point of view educational level don't always affect the quality of care provided but affect on the level of awareness regard any type of activity provided.

Results of the current study illustrated that more than half of participants' known the mode of transmission of typhoid as polluted food and water while forty four point one don't. This result in agreement with the study carried out by Malisa and Nyaki [14] on 120 participants in Tanzania found that more than half (57.5\%) of study subjects don't know the mode of typhoid transmission while forty two point five known. The results also showed that majority of participants' known that typhoid affects all age groups and about two third mentioned children aged between 1 and less than 6 years commonly affected by typhoid followed by more than one quadrant (28.8\%) aged between 6 and 13 years. This result supported by Dewan AM, Corner R, Hashizume M, Ongee ET [1] who study typhoid fever and its association with environmental factors in the Dhaka metropolitan area of Bangladesh on 455 participants' found that more than half of study subjects aged under five years.

Result of the current study revealed that half of participants' don't know environmental risk factors such as polluted water and improper sewage disposal system as risk factors for typhoid while majority of them known the personal risk factors such as hygiene and food preparation as $\mathrm{s}$ a risk factor. From my point of view these results directly affect the practices of the study subjects especially in preventive measures of the disease and the available precautions toward the environment they live in.

Regarding food habits practices, results of the current study revealed that majority of participants' mentioned that most of meals are home made and these meals almost prepared by the mother. Results also revealed that one third of participants' sale out door meals, majority $(92.2 \%)$ of them sale it from shop or restaurant while seven point eight percent sale it from peddlers sold. Majority of these out door meals were cooked meals while only eight point eight percent were raw food. Furthermore all Participants had out door drinks. From my point of view these unhealthy habits made participants' at dual burden either improper hygienic measures within the raw food or contamination of cooked meals or drinks at any point of administration and both put them under risk of infection.

These results and point of view were supported by the study done by Siddiqui, Bibi, Mustufa, Ayaz and Khan [17] on 209 food handlers to study high prevalence of typhoid Salmonella enterica serovars excreting food handlers in Karachi-Pakistan: A probable factor for regional typhoid endemic found that around one tenth of them were positive for typhoid bacteria. This result put an alert for study subjects as a caregivers eating out door once increase sustainability for infection.

Regarding personal hygiene practices, result of the current study revealed that around two third of participants' washed their hands after retune home while more than one third didn't. The result also revealed that majority of participants' washed hands before food preparation while don't regularly washed it before eating. This results in arrangement with the result reported by Nguri [16] who study risk factors influence typhoid fever occurrence among the adults in Maina slum,Nyahururu municipality, Kenya that found majority of his study subjects didn't wash hands before eating.

Results also revealed that only one third of participants' washed hands after toilet while two third didn't. This results supported by the results of Nguri [16] who reported that around two third of his study subjects didn't regularly washed hands after toilet. In my point of view this main risk factor that directly affect on food and water manipulation either for self or others especially in such fecal-oral infections. This point of view is supported by Wali, Hasaneen, Almoslmani, Salem and Abbas [11] who mentioned that Typhoid is a serious public health problem in Egypt and reported that hand washing is an effective prevention strategy.

Concerning water storage almost of study subjects hah water tanks placed inside the house. Majority of them put water tanks in the kitchen, 
while one quarter put it in the bathrooms. More than one third store water for one week while one quarter store it more than two weeks and till water turned off. From my point of view water storage needs a lot of precautions such as stored in clean and safe containers, stored for only days and replace it, stored away of any contamination specially bathrooms and separate between drinking water and other usage containers.

Results of the study revealed that all participants' had trenches sewage disposal system at home. In my point of view it could be source of many infections specially if not treated by a specialist, its distance from the surface, frequency of emptying it and observation for leakage but this area is not properly assessed in this study. Moreover half of study subject collect food wastes in plastic bag for discharge while the others collect it for the home birds and animals in my point of view this could be a source of flies and so transmission of many organisms.

Regarding setting of the home environment as observed by the research investigator, majority of Participant's homes were away canals, while two third of these homes near garbage collections (street peddlers for fish or uncovered sweets or garbage). More than two third of Participants had over all cleaned children and majority of them had clean homes while only half of them had well ventilated homes. Concerning insects (flies) sixty point four percent had insects at home while only half of them control it and so had intact silk at the home outlets. From my point of view presence of the home near to garbage is a risk for many diseases and increase presence of insects that in many diseases transmit the infections beyond the community members especially in absence of proper ventilation and entrance of sunlight.

Regarding water supply, all participants' had governmental water supply and majority of them had running water at the kitchen but $43.5 \%$ of water supply weren't safe for drinking either changed color or clarity as observed and this percentage was near that reported by study subjects. Moreover one third had unclean storage tanks for water. From my point of view unsafe water supply is the great risk for the spread of typhoid. Furthermore, improper storage of drinking water for along time as mentioned before sometimes till water turned off. Concerning bathrooms, all participants' had special bathroom for their homes but around half weren't clean (wet, bad Oder and presence of flies). From my point of view this was the great risk for typhoid transmission (fecal-oral cycle) with lack of hand wash after toilet use specially if there were any typhoid carrier at the family.

Regarding correlation between total knowledge, total practice \& total home environment and previous family history of typhoid, the results revealed highly statistical significant negative correlation between total knowledge and family history of typhoid. From my point of view previous history is the best reference of knowledge and directly reflected positively on quality of healthy practices and home environment sanitation and so prevention of typhoid spread. On the other hand lack of knowledge in presence of family history could be nucleus for further transmission of typhoid within the family and the community.

Regarding correlation between total knowledge, total practice and home environment with each other, there were highly positive statistical significant correlation between total knowledge and total practices. From my point of view there could be correlation between total knowledge, total practices and home environment if this study applied in another setting or population.

\section{Conclusion of the study:}

The study concluded that not all participants' had correct knowledge about transmission and prevention of typhoid and so applied major faulty health practices within the home environment that put them at risk for the infection such as hand hygiene after toilet and before eating. So the study concluded that the risk of typhoid transmission not only affected by sanitation of the environment but also the practices within this environment.

\section{Recommendation of the study:}

The study recommended a program for safe water supply, increase public awareness for typhoid and its prevention including hygiene practices, specially, hands washing and Regular examination of food handlers. It also recommend, urgent and continuous monitor of water supply systems and detect any leakage or fecal.

\section{References}

1- DEWAN A.M., CORNER R., HASHIZUME M. and ONGEE E.T.: Typhoid Fever and its association with environmental factors in the Dhaka Metropolitan Area of Bangladesh: A spatial and time-series approach. PLoS. Negl. Trop. Dis., 7 (1): e1998. doi: 10.1371/journal.pntd. 0001998. Epub 2013 Jan 24, 2013.

2- World Health Organization (WHO): Water-related diseases. Available at http://www.who.int/water-_sanitation-_health/ diseases/typhoid/en/, 2014. 
3- Mayo Clinic staff. Typhoid risk factors. Available at http://www.mayoclinic.com/health/typhoid-fever/ DS00538/DSECTION=risk-factors, 2012.

4- World Health Organization (WHO). Food borne diseases. Available at http://www.who.int/topics/foodborne_diseases . len/. 2013.

5- ABDULKARIM Y.: Environment and Socioeconomic Influence of Victim of Malaria and Typhoid Fever in Nigeria, IOSR Journal of Humanities and Social Science (JHSS), Volume 2, Issue 3, 2012.

6- SHAFFER, MICHAEL, SPADER and CATHERINE RN.: Typhoid fever causes in infections and contagious diseases. available at http://www.localhealth.com , 2011.

7- American Public Health Association (APHA). The Role of Public Health Nurses available at http://www.apha.org/ memb ergroup s/sections/-aphas ections/-phn/about/ph nroles.htm, 2013.

8- Centers for Disease Control and Prevention, Chapter 3 Typhoid and Paratyphoid Fever. The Yellow Book. Available at: http://wwwnc.cdc.gov travel/Yellowbook/ 2010, 2013.

9- ABDELRAHEEM N.M., YOUSEF G.Y., SHALABY H.M. and ABDELAZZIZ M.E.A.: Study of Typhoid Carriers among Children in Sohag. Available at http://www.pediatr iconcall.com/m/doctor/Original Articles/typhoid.asp, 2007.

10- MOGASALE V., MASKERY B., OCHIAI R.L., et al.: Revisiting the burden of typhoid fever in low- and middleincome countries for policy considerations. Lancet Glob Health, 2: e570-80, 2014.
11- WALI, HASANEEN, ALMOSLMANI, SALEM and ABBAS: Personal hygiene and household habits relation to typhoid outbreak in rural Sharkia Governorate. In The Egyptian Journal of Community Medicine, Vol. 29 No. 2 April 2011.

12- MRORION: Recent outbreaks of typhoid in Egypt. Available at http://www.allvoices.com/contributed-news/ 3914683-recent-outbreaks-of-typhoid-in-egypt, 2009.

13- SRIKANTIAH P., GIRGIS F.Y., LUBY S.P., JENNINGS G., WASFY M.O., CRUMP J.A., HOEKSTRA R.M., ANWER M. and MAHONEY F.J.: Study of PopulationBased Surveillance of Typhoid Fever In Egypt. Am. J. Trop. MED. Hyg. January, Vol. 74 No. 1: 114-119, 2006.

14- MALISA and NYAKI: Prevalence and constraints of typhoid fever and its control in an endemic area of Singida region in Tanzania: Lessons for effective control of the disease, 2010.

15- NAQQASH, SAEED, SAEED, JALEEL, ZAKA, FAHEEM, BAKHTAWAR and REHMAN: A Cross Sectional Survey of Community Awareness about Typhoid and its Major Vector Cockroach in Southern Punjab, Pakistan. in Middle-East Journal of Scientific Research, 21 (4): 602-608, 2014.

16- NGURI: Typhoid risk fators and history to study risk factors influence typhoid fever occurrence among the adults in Maina slum, Nyahururu municipality, Kenya, 2011.

17- SIDDIQUI, BIBI, MUSTUFA, AYAZ and KHAN: Prevalence of typhoidal Salmonella enterica serovars excreting food handlers in Karachi-Pakistan: A probable factor for regional typhoid endemicity, 2015. 


\section{العلاقة بين عوامل الخطورة البيئية ومرض التيفويل \\ بين الأطفال والقائمين على رعايتهم \\ بمحافظة القليوبية}

هدف الدراسة: التعرف على العلاقة بين عوامل الخطودة البيئية ومرض التيفود بين الأطفال والقائمين على رعايتهم بمحافظة القليوبية. تصميم الدراسة: تم إستخدام بحث إرتباط وصفى لدراسة العلاقة بين عوامل الخطودة البيئية ومرض التيفود بين الأطفال والقائمين على رعايتهم بمحافظة القليويية.

مكان تتفيذ الدراسة: أجريت الدراسة فى ع قرى بمحافظة القليوية. ينتشر بهذه القرى الفقر، إنتشار العادات غير الصحية ولا يوجد نظام صرف صحى. عينة الدراسة: إشتملت عينة البحث على (TIM) من مقدمى الرعاية لدايهم أطفال تتراوح أعمارهم من سنة إلى خمس سنوات ويتردد على أى من الأربع مراكز صحية التى تخدم القرى محل الدراسة. أدوات جمع البيانات: تم تجميع اليانات الخاصة بالدراسة بواسطة أداتين: إستيان وأستمارة ملاحظة لبيئة المنزل تم تطويرهم بواسطة الباحث بعد إعتماده على المراجع العلمية العديثة.

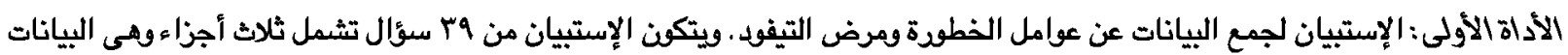
الديموجرافية والمعرفة العامة عن مرض التيفود وممارسات المشاركين تجاه عوامل الخطورة للتيفود . كما تم إستخدام إستمادة لملاحظة بيئة المنزل الداخلية والخارجية.

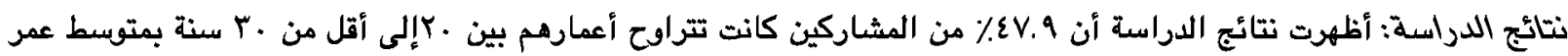


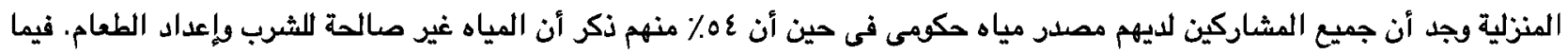

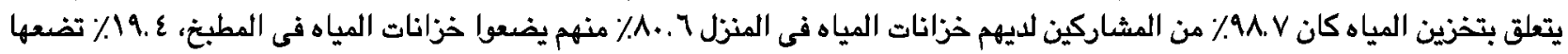

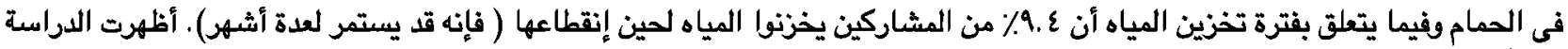

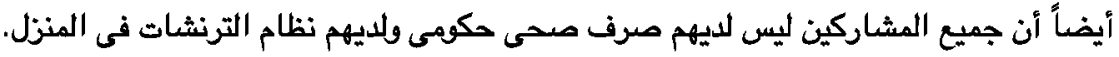

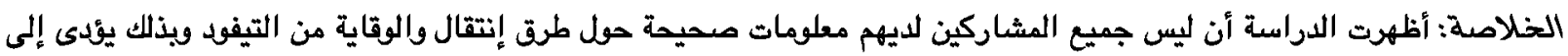

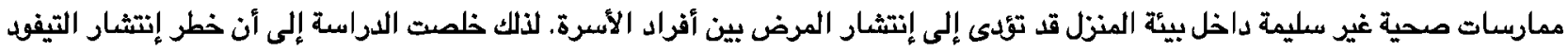
لا يتأثر فقط بالعوامل الييئية ولكن بالممارسات داخل هذه اليئية الئية

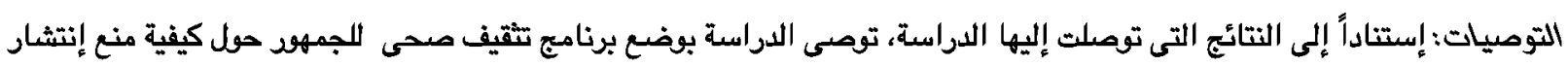

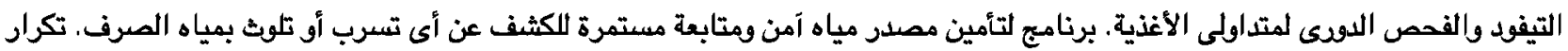
الدراسة لمعرفة العوامل التى تزيد من إعادة إنتشار التيفود في أماكن أخرى ألتين. 